\title{
Проблемы формирования транспортной системы Сибирской Арктики ${ }^{1}$
}

Л.А. БЕЗРУКОВ, доктор географических наук, Институт географии им. В.Б. Сочавы СО РАН, Иркутск. E-mail: bezrukov@irigs.irk.ru

Рассмотрены актуальные вопросы транспортного освоения арктических территорий Сибири - Тюменской и Красноярской Арктики. Раскрыты основные достижения в развитии транспорта Тюменской Арктики, состоящие в приобретении Северным морским путем (СМП) новых важных функций по перевозке нефти и сжиженного природного газа, поступательном строительстве наземной коммуникационной инфраструктуры - железных дорог и круглогодичных автодорог. Отмечены недостатки в развитии транспортной системы Красноярской Арктики, выражающиеся в наличии почти исключительно сезонных путей с доминированием речного и морского транспорта, безальтернативности действующих транспортных схем и чрезвычайно высоком уровне транспортных издержек. Дан анализ приоритетов и функций СМП, подтверждено возрастание его значимости главным образом в транспортно-логистическом обслуживании крупных нефтегазовых и других ресурсных проектов и вывозе из прибрежных районов сырьевой продукции на внешний и внутренний рынки.

Ключевые слова: Тюменская и Красноярская Арктика, Северный морской путь (СМП), транспортное освоение и обслуживание, круглогодичные наземные пути, сезонные пути, завоз грузов, грузопоток, транзитные перевозки

Главными звеньями транспортно-инфраструктурного каркаса освоения и обслуживания Азиатской России, или «большого сибирского кольца», служат широтно ориентированные Транссибирская железнодорожная магистраль (Транссиб) на юге и Северный морской путь (СМП) на севере. При этом Транссиб и растущая от него сеть железных дорог осуществляют целостное функционирование южной части макрорегиона, тогда как СМП и речные меридиональные артерии (Обь, Надым, Пур, Таз, Енисей, Хатанга, Лена и др.) обеспечивают хозяйственную консолидацию территории с севера на юг. Важный недостаток такой транспортной системы состоит в слабой связи между собой главных широтных коммуникаций (Транссиб - СМП): в пределах всей Сибири на Транссиб и одновременно на СМП опираются только судоходные магистрали Обь и Енисей, а от Транссиба

\footnotetext{
${ }^{1}$ Работа выполнена при поддержке РФФИ и РГО в рамках проекта 17-05-41057 РГО_а.
} 
до Северного Ледовитого океана (Обской губы) доходит лишь одна субмеридиональная железная дорога Тюмень-ТобольскСургут-Новый Уренгой-Ямбург.

К Сибирской Арктике, тяготеющей к СМП, согласно законодательному выделению Арктической зоны РФ, относятся северные территории Сибирского ФО в границах Ямало-Ненецкого автономного округа Тюменской области (Тюменская Арктика), г. Норильска, Таймырского Долгано-Ненецкого и Туруханского муниципальных районов Красноярского края (Красноярская Арктика). Ситуация с транспортным освоением арктических районов Сибири весьма неоднозначна. Если для Тюменской Арктики в этом отношении характерны значительные позитивные изменения, то транспортная система Красноярской Арктики существенно отстает в своем развитии

\section{Транспортный «прорыв» Тюменской Арктики}

Заметные успехи в транспортном освоении Тюменской Арктики связаны с реализацией крупных ресурсных проектов, основанных на масштабной добыче и транспортировке нефти и природного газа. Выход нефте- и газодобычи к океану коренным образом меняет схему грузопотоков, поскольку функции по перевозке на экспорт углеводородов все в большей мере берет на себя СМП, а не традиционный трубопроводный транспорт.

С 2017 г. приступил к регулярным поставкам сжиженного природного газа (СПГ) новый морской порт Сабетта на левом берегу Обской губы вблизи ее выхода в Карское море. Продукция завода «Ямал СПГ» проектной мощностью 16,5 млн т в год вывозится из Сабетты по СМП специальными танкерами-газовозами ледового класса длиной 300 м и осадкой 11 м (в зимний период с ледокольной проводкой $)^{2}$.

С 2016 г. началась перевозка нефти челночными танкерами из Нового Порта (левый берег Обской губы), причем непосредственная отгрузка осуществляется находящимся в 100 км от него нефтеналивным терминалом «Ворота Арктики» (Мыс Каменный). Указанные танкеры в арктическом исполнении имеют грузоподъемность около 35 тыс. т и осадку 9 м, работают зимой

${ }^{2}$ Морской порт Сабетта показал рекордный грузооборот в 2017 году [Эл. ресурс]. URL: http://seablue ru/2018/01/15/morskoj-port-sabetta-pokazal-rekordnyj-gruzooborotv-2017-godu/ (дата обращения: 14.03.2018). с ледокольным обеспечением; в Мурманске нефть перекачивается на танкеры большей грузоподъемности ${ }^{3}$. Нефтеналивной терминал имеет мощность до 8,5 млн т нефти в год.

С 2007 г. ведется строительство морского порта в Харасавэе (западное побережье п-ва Ямал) для вывоза по СМП нефти и газового конденсата в объеме до 11-12 млн т в год 4 . В будущем Харасавэй может принимать танкеры осадкой 11,5 м как в летний, так и в зимний период.

Кроме того, функции морского порта способен выполнять Ямбург (правый берег Обской губы) - единственное место не только в Тюменской Арктике, но и во всей Азиатской России, где железная дорога вышла непосредственно к Северному Ледовитому океану. В настоящее время глубины в акватории этого порта невелики - 5-6 м, но существует проект его модернизации с увеличением глубин до $8 \mathrm{~m}^{5}$.

Другая важная составляющая транспортного развития Тюменской Арктики - создание наземной коммуникационной инфраструктуры - железных дорог и круглогодичных автодорог с твердым покрытием. Субмеридиональная железнодорожная линия от Тюмени до Ямбурга позволила «распечатать» колоссальные запасы природного газа Уренгойского и Ямбургского месторождений, а линия длиной 525 км от станции Обская Северной (Печорской) железной дороги до Бованенково - запасы Бованенковского месторождения на полуострове Ямал [Пономарев, 2017]. Ведется строительство линии Бованенково-Сабетта протяженностью 170 км, что позволит организовать доставку в Сабетту практически любых грузов и превратить его в многофункциональный морской порт и главный опорный пункт СМП. Планируются также железнодорожные соединения линии Обская-Бованенково с портами Харасавэй и Новый Порт.

Особое значение для развития коммуникационной инфраструктуры Сибирской Арктики имеет строительство Северного широтного хода, который свяжет Северную и Свердловскую

3 Проект «Новый Порт» [Эл. ресурс]. URL: http://www.gazprom-neft.ru/company/ business/exploration-and-production/new-projects/new-port/ (дата обращения: 14.03.2018)

${ }^{4}$ Доставка грузов в порт Харасавэй ЯНАО Ямал, проектные грузоперевозки [Эл. pecypc]. URL: https://belomortrans.ru/ru/area-delivery/ufo/yanao/kharasavej (дата обращения: 14.03.2018).

Порт Ямбург планируется модернизировать [Эл. ресурс]. URL: http://rus-shipping. ru/ru/infstruct/news/?id=27547 (дата обращения: 14.03.2018). 
железные дороги, т.е. станцию Обская (Лабытнанги) и Надым. Магистраль сократит расстояние и время перевозки грузов севера Западной Сибири до портов Балтики, соединит западную и восточную части ЯНАО. Кроме строительства линии Обская-Салехард-Надым длиной 388 км, требуется реконструкция участка Надым-Пангоды-Новый Уренгой-Коротчаево длиной 319 км [Пономарев, 2017]. Соглашение о совместной реализации инвестиционного проекта по строительству Северного широтного хода подписано ОАО «РЖД» и ОАО «Газпром» в 2017 г. В перспективе этот ход может быть продолжен в восточном направлении в Красноярскую Арктику с выходом на Игарку и Дудинку, что обеспечит присоединение Норильска к сети железных дорог страны.

На территории ЯНАО действуют круглогодичные автодороги Сургут-Муравленко-Уренгой-Надым, Новый Уренгой-Ямбург, Уренгой-Тазовский, Надым-Приозерный. В одном технологическом коридоре с железнодорожным Северным широтным ходом идет строительство автодороги Надым-Салехард длиной 344 км, призванной решить важные в социальном плане задачи улучшения транспортного обслуживания северян. Строится также спрямляющая автодорога Муравленко-Надым.

Быстро меняется к лучшему инфраструктура воздушного транспорта. Только в последние годы введены в эксплуатацию два новых аэропорта - в Бованенково и Сабетте. Значительные объемы авиаперевозок осуществляют аэропорты Нового Уренгоя (более половины авиаперевозок ЯНАО), Ноябрьска, Надыма и Салехарда, а также Ямбурга, Красноселькупа, Тазовского и др. Стабильны перевозки водным транспортом, который работает главным образом на Оби, Надыме, Тазе и Пуре, в Обской и Тазовской губах.

Мощное развитие в последние годы получил традиционный для Тюменской Арктики трубопроводный транспорт. Введена в эксплуатацию система магистральных газопроводов по направлению Бованенково-Ухта, представляющая собой самый северный (ямальский) коридор Единой системы газоснабжения России (компания ОАО «Газпром»). Построен магистральный нефтепровод Заполярье-Пурпе-Самотлор, входящий в общую систему нефтепроводов России (компания ОАО «АК Транснефть»).
Вместе с тем в транспортном освоении Тюменской Арктики имеются, конечно, и существенные недостатки. Во-первых, далеко не всё из намеченного удалось осуществить на практике. Так, отложена реализация строительства субмеридиональной железной дороги вдоль Урала по направлению Полуночное-Обская-Салехард.

Во-вторых, по ряду причин не все из построенных транспортных объектов находятся в эксплуатации. Примером служит ситуация с железной дорогой Новый Уренгой-Ямбург, движение по которой было открыто еще в 1986 г., но официально в действие она не вводилась и работала в режиме временной эксплуатации. С 2015 г. арендующая эту линию Ямальская железнодорожная компания остановила по ней движение в связи с неудовлетворительным техническим состоянием и прекращением финансирования со стороны собственника - ПАО «Газпром» ${ }^{6}$. Точка зрения собственника - дорога свою задачу по освоению Ямбурга выполнила и можно избавиться от «балласта», точка зрения региона - необходимо развивать транспортную инфраструктуру, а не оставлять после себя «мертвые» дороги.

В-третьих, определенные сомнения возникают в отношении экономической эффективности некоторых масштабных транспортных проектов. По мнению экспертов [Россия..., 2015; Поворот..., 2016], недостаточно ясна экономическая целесообразность предложений по превращению Сабетты в универсальный морской порт и подведению к ней железной дороги. Следует учитывать, что помимо экстремальных природно-климатических условий судоходство в Обской губе и других прибрежных акваториях п-ва Ямал сильно затрудняется и удорожается относительно небольшими глубинами. В связи с этим все вводимые здесь в эксплуатацию глубоководные морские порты имеют искусственный характер. Например, для обеспечения работы порта Сабетта осуществлены огромные вложения в создание 49-километрового морского канала (шириной 300 м и глубиной 15,1 м) при впадении Оби в Карское море и шестикилометрового

6 «Газпром» закрывает на Ямале 200 километров железной дороги [Эл. ресурс]. URL: https://www.znak.com/2015-06-04/proekt na kotoryy byli potracheny milliardy koncernu ne nuzhen foto (дата обращения: 14.03.2018). 
подходного канала (шириной почти 500 м и глубиной 15,1 м) 7 . Мелководность характерна также для Харасавэя, Нового Порта, Ямбурга и других портов.

В-четвертых, несмотря на успешную реализацию ряда крупных транспортных проектов, значительная часть Тюменской Арктики остается без круглогодичных наземных путей сообщения. До сих пор юго-западная (Шурышкарский район) и юго-восточная (Красноселькупский район) части ЯНАО не имеют устойчивой круглогодичной связи с Большой землей. Инвестиции по-прежнему вкладываются в проекты, необходимые непосредственно крупнейшим ресурсодобывающим компаниям, тогда как насущные интересы муниципальных районов и местного населения остаются на заднем плане.

\section{Транспортное обслуживание Красноярской Арктики}

Арктические территории, занимающие 46,3\% общей площади Красноярского края, имеют исключительно большую значимость для развития его экономики. Если удельный вес этих территорий в численности населения края невелик $-7,9 \%$, то по объему отгруженных товаров (объему промышленного производства) в 2011-2016 гг. он достиг 52-60\%, в объеме инвестиций в основной капитал - 35-45\%, в доходной части бюджета края - не менее 50-60\%. Основную роль в экономике арктических территорий края играют сегодня два системообразующих предприятия-Заполярный филиал ГМК «Норильский никель» (городской округ Норильск) и $3 \mathrm{AO}$ «Ванкорнефть» НК «Роснефть» (Туруханский район).

От других сухопутных территорий Арктической зоны России Красноярскую Арктику отличает целый ряд уникальных экономико-географических (в первую очередь транспортно-географических) особенностей, которые во многом определили своеобразный ход и весомые результаты освоения северной части края. Не менее значимы они и для дальнейшего развития его арктических территорий.

Первая и совершенно уникальная черта Красноярской Арктики состоит в наличии в низовьях Енисея естественного

Строительство объектов морского порта Сабетта на полуострове Ямал, включая создание судоходного подходного канала в Обской губе [Эл. pecypc]. URL: http://www. rosmorport.ru/filials/arf port development/ (дата обращения: 14.03.2018). глубоководного пути, доступного для морских судов. Благодаря таким внутренним глубоководным путям, транспортно-экономическое влияние Мирового океана может проникать далеко вглубь материка, что резко сокращает издержки на перевозки [Безруков, 2005]. Морские суда грузоподъемностью до 15 тыс. т могут подниматься вверх по Енисею до Дудинки (423 км от устья), грузоподъемностью до 10 тыс. т - до Игарки (685 км от устья) [Бандман, 1999].

Енисей - единственная река не только российской, но и всей Арктики, имеющая на столь большом протяжении благоприятные условия для экономичного морского судоходства; внутренние водные сверхмагистрали такой протяженности представлены в мире поистине «поштучно» - Амазонка, Янцзы, Парана, р. Святого Лаврентия с Великими озерами. Другие крупнейшие речные магистрали бассейна Северного Ледовитого океана-Обь и Лена - по условиям судоходства (недостаточность глубин) не могут конкурировать с Енисеем. Все это не отменяет, конечно, того факта, что эффективность морских перевозок в низовьях Енисея из-за длительного ледостава существенно ниже, чем на доступных для морских судов незамерзающих реках мира (например, на Амазонке или Янцзы).

Второй уникальной чертой Красноярской Арктики следует считать то обстоятельство, что благодаря большим гарантированным глубинам низовьев Енисея, позволяющим применять ледоколы и суда ледового класса, СМП в западном секторе Арктики на линии Мурманск-Дудинка с конца 1970-х гг. стал функционировать в режиме продленной навигации, а по существу превратился почти в круглогодичную транспортную магистраль. Морская навигация прерывается только в конце мая-июне в связи с прохождением пика весеннего половодья на Енисее. Вывоз норильских руд морским путем из Дудинки в Мурманск привел к радикальному снижению транспортных затрат и повышению рентабельности работы норильского комбината [Аганбегян, 1984]. Маршрут Мурманск-Дудинка до самого последнего времени оставался единственной регулярной и практически круглогодичной линией СМП на всей его официально установленной акватории от проливов архипелага Новая Земля до Берингова пролива. В то же время новые арктические порты Карского моря на территории соседнего ЯНАО еще только 
приступают к работе, испытывая значительные трудности из-за малых глубин.

Обе вышеназванные уникальные черты во многом обусловили третью - превращение Норильска в самый крупный индустриальный центр Арктики (отечественной и зарубежной) и один из крупнейших промышленных центров России. По объему промышленного производства в 2015 г. Норильск входил в первую десятку российских городов и значительно превосходил другие арктические города страны - Мурманск, Архангельск, Новый Уренгой, Воркуту и пр. Норильский промышленный район по праву выступает как опорная база хозяйственного освоения всей центральной части Арктической зоны России. Есть веские основания считать, что Норильск, обладающий мощной энергетической, строительной и кадровой базой, может стать в будущем ядром формирования крупнейшего Северо-Енисейского территориально-производственного комплекса [Аганбегян, 1984] (в последних редакциях - Норильско-Туруханского и Таймырского комплексов [Бондаренко и др., 2012]), в промышленный оборот которого войдут огромные пространства Таймыра, континентального шельфа и островов Северного Ледовитого океана

Четвертая уникальная черта заключается в том, что Красноярский край (вместе с Иркутской областью) остается индустриальным форпостом в восточной части России, поскольку далее к востоку - в Забайкалье и на Дальнем Востоке - нет промышленных районов такого масштаба и разносторонности. Не случайно сам краевой центр Красноярск, получивший несколько лет назад статус «миллионера», является крупнейшим городом всей заенисейской половины страны, а Норильск - ее крупнейшим промышленным центром. Благодаря преимуществам своего географического положения и меридионального простирания от Саян до Северного Ледовитого океана, Красноярский край призван служить базой освоения сибирских Севера и Арктики.

Однако названные выгоды в значительной степени «нивелируются» отсутствием надежной круглогодичной транспортной связи между южными (прижелезнодорожными) и северными (в том числе арктическими) районами. Если в соседнем ЯНАО железные дороги или уже вышли к Карскому морю (Ямбург), или в ближайшем будущем сразу в нескольких местах могут выйти к нему (Сабетта, Харасавэй, Новый Порт), то для Красноярского края подобные железнодорожные соединения просматриваются лишь в более отдаленной перспективе.

Несмотря на благоприятные предпосылки транспортно-географического характера, территория Красноярской Арктики до сих пор обслуживается почти исключительно сезонными путями. Подавляющая часть грузов перевозится водным транспортом - речным и морским, отчасти автомобильным по автозимникам, тогда как железнодорожный и трубопроводный виды транспорта имеют локальное значение, а воздушный используется преимущественно для доставки пассажиров. В труднодоступных районах до сих пор широко применяются вездеходы, представители коренных народов используют олений и собачий транспорт (перевозки на нартах).

Наиболее мощной воднотранспортной магистралью, связывающей Красноярскую Арктику с южными районами края с одной стороны, и Северным Ледовитым океаном - с другой, является меридиональная ось Енисея. Опорными речными и морскими портами служат здесь Дудинка (аванпорт Норильска) и Игарка, к числу важных пристаней относятся Туруханск, Прилуки (причал ЗАО «Ванкорнефть»), Бор и др. Подавляющую часть (около 90\%) всего объема перевозок вниз по Енисею (2,5 млн т в 2016 г.) составляют грузы, транспортируемые из Красноярска и Лесосибирска для нужд Норильского промышленного района (в Дудинку) и Ванкорского нефтегазового кластера (вверх по Бол. Хете к вахтовым поселениям).

Остальная часть грузов, завозимая речным транспортом, предназначена для пунктов по самому Енисею и его судоходным притокам - Дубчесу, Елогую, Турухану, Курейке, Хантайке, Бол. Хете. Судоходство на притоках Енисея осуществляется в гораздо более трудных условиях, чем на главной магистрали, вследствие ограниченных габаритов судового хода, короткого периода навигации, дефицита специализированного малотоннажного флота, низкой эффективности перевозок. Если период навигации по Енисею продолжается четыре месяца, то на большинстве притоков-лишь 7-20 дней (во время весенне-летнего половодья). Например, завоз грузов по Бол. Хете для вахтовых поселений Ванкора возможен только мелкосидящими судами грузоподъемностью до 200 т 
в течение одной недели июня на пике половодья; нижнее течение Пясины, пригодное для речных судов, в настоящее время почти не используется.

На втором месте по объему перевозок в Красноярской Арктике находится морской транспорт. По СМП из Мурманска в Дудинку через Баренцево и Карское моря в 2016 г. доставлено 0,6 млн т грузов, в обратном направлении - 0,7 млн т. Грузооборот порта Игарка в настоящее время очень мал, а морские перевозки имеют эпизодический характер. Грузооборот морского порта Диксон сейчас также относительно незначителен - 0,03-0,04 млн т, но имеются большие перспективы роста.

Исключительно по СМП осуществляется завоз грузов в морской порт Хатанга, находящийся в 200 км выше устья одноименной реки (море Лаптевых) и доступный для судов смешанного плавания «река-море» и малотоннажных морских судов. Ocновным направлением поставок является восточное (из Тикси), но в отдельные годы часть грузов идет из низовьев Енисея вокруг Таймыра. Объем перевозок невелик - 0,05-0,07 млн т. Часть грузов, завезенных морским путем, уходит далее на речных судах в населенные пункты как на самой Хатанге, так и на ее притоках - Хете, Котуе и Попигае.

С 2016 г. в 50 км от Диксона ведется строительство морского порта «Чайка» - первого глубоководного угольного терминала в Арктической зоне России ${ }^{8}$. Разработка месторождений ценных коксующихся углей Западно-Таймырского угленосного района (проект «Тайбасс») может стать новым прорывным направлением развития Красноярской Арктики. По мнению разработчиков ${ }^{9}$, это будет высокорентабельное производство, поскольку добыча коксующихся углей планируется в непосредственной близости (15 км) от морского порта, т.е. без затрат на железнодорожную перевозку. Уже в 2020 г. предусмотрено выйти на объемы добычи в 15 млн т, в 2030 г. - в 30 млн т углей в год, которые будут вывозиться на внешний рынок по СМП. Уголь планируется поставлять

${ }^{8}$ Арктическая горная компания и «Трест Запсибгидрострой» расширяют сотрудничество в Арктике [Эл. pecypc]. URL: http://www.korabli.eu/blogs/novosti/morskie-novosti/ arkticheskaya-gornaya (дата обращения: 14.03.2018).

${ }^{9}$ Исаев А. С. Хотим, чтобы Диксон стал мировой столицей Арктики. Интервью председателя правления УК «ВостокУголь»о от 29 марта 2017 г. [Эл. ресурс]. URL: http://vostokcoal.ru/news/2017/03/29/vostokugol-hotim-chtoby-dikson-stal-mirovoj-stolicejarktiki/ (дата обращения: 31.08.2017) из порта «Чайка» судами-балкерами с ледовым усилением и грузоподъемностью до 76 тыс. т (в зимний период с ледокольной проводкой $)^{10}$. Следует отметить, что еще в советский период известные экономисты [Аганбегян, 1984] указывали, что коксующиеся угли Таймыра могут оказаться дешевле южноякутских, а их экспортные перевозки морем - экономичнее, чем доставка кузнецких углей по Транссибу. Расчеты для современных условий показывают, что перевозка углей с побережья Таймыра в Западную Европу по СМП вдвое дешевле транспортировки кузнецких углей из Кузбасса через Мурманск в Нидерланды ${ }^{11}$.

Железнодорожный транспорт Красноярской Арктики представлен изолированной («островной») ведомственной железной дорогой Норильск-Дудинка, протяженностью 89 км, которая предназначена для доставки грузов ГМК «Норильский никель» в порт. Параллельно проложена единственная круглогодичная автомобильная дорога длиной 85 км.

Из-за отсутствия круглогодичных автодорог с твердым покрытием значительную роль в перевозках грузов в населенные пункты Красноярской Арктики, удаленные от речных и морских путей, играют автозимники, общая протяженность которых достигает нескольких тысяч километров. Автозимники обеспечивают сезонную транспортную доступность в течение 4-5 зимних месяцев и несут основную нагрузку по доставке в отдельные поселения нефтепродуктов, угля, товаров народного потребления и продуктов питания.

Трубопроводный транспорт до недавнего времени обслуживал внутренние нужды региона. Так, действующий несколько десятилетий газопровод Мессояха-Норильск подает природный газ из месторождений левобережья Енисея для нужд энергетики Норильского промышленного района. Лишь в результате освоения Ванкорского месторождения была проведена «труба» до магистрального нефтепровода Ванкор-Пурпе, подключившая Ванкор к общей системе нефтепроводов России, и построен газопровод Ванкор-Хальмерпаюта с включением в Единую систему газоснабжения страны.

${ }^{10}$ Арктическая горная компания и «Трест Запсибгидрострой» расширяют сотрудничество в Арктике [Эл. peсурс]. URL: http://www.korabli.eu/blogs/novosti/morskie-novosti/ arkticheskaya-gornaya (дата обращения: 14.03.2018)

${ }^{11}$ Исаев А.С. Указ. соч. 
В пассажирских перевозках основное значение имеет дорогостоящий воздушный транспорт, обеспечивающий круглогодичную связь Красноярской Арктики с Большой землей. Хотя рейсовые пассажирские перевозки осуществляются в 13 населенных пунктах, ежедневное сообщение имеется только с Норильском. Авиасвязь с другими пунктами производится в среднем один раз в неделю: из аэропортов Красноярска - в Игарку, Светлогорск, Туруханск, Хатангу, Подкаменную Тунгуску и др., из Норильска - в Диксон, Хатангу и Снежногорск. В большинстве остальных населенных пунктов имеются только вертолетные посадочные площадки, используемые эпизодически, а в самых малых пунктах и они отсутствуют, так что местное население лишено возможностей круглогодичного транспортного сообщения.

Сезонная пассажирская связь обеспечивается речным транспортом. По Енисею существует пассажирское сообщение от Красноярска до самого устья: рейсы имеются от Красноярска до Дудинки (с середины июня до начала октября) и от Дудинки до Воронцово (с конца июня до конца сентября). По притокам Енисея пассажирские рейсы отсутствуют. От порта Хатанга действуют пассажирские маршруты: по Хатанге до Сындасско и Попигаю до Попигая (с начала июля до середины сентября), по Котую до Каяка (с середины июня до конца июля), по Хете до Катырыка (с середины июня до начала июля). В остальное время года пассажирское речное сообщение отсутствует, т.е. поселения изолированы от Большой земли и друг от друга.

Для основной части населенных пунктов Красноярской Арктики типичны безальтернативность действующих транспортных схем и ограниченность взаимозаменяемости видов транспорта и путей сообщения, что обусловливает чрезвычайно высокий уровень транспортных издержек. С сезонностью перевозок связаны не только непосредственные транспортные затраты, но и дополнительные издержки по созданию значительных сезонных и страховых запасов товаров и их хранения. При распространенных в Арктике многозвенных транспортных схемах грузы могут «омертвляться» в пути на весьма продолжительное время - до 1-1,5 лет. С учетом высоких транспортно-логистических расходов, 60-70\% всех затрат связано в Арктике с транспортом [Аганбегян, 1984; Поворот.., 2016]. Поэтому перспективы дальнейшего освоения Арктики будут в значительной мере определяться успехами в развитии и модернизации магистральной транспортной инфраструктуры.

\section{Приоритеты Северного морского пути}

Развитие арктических территорий Сибири сильно зависит от выбора приоритетов и функций СМП и вариантов решения проблемы его правового статуса. В настоящее время морской транспорт обеспечивает в Арктике следующие виды перевозок: 1) снабжение предприятий и населения, включая «северный завоз»; 2) транзитные перевозки по СМП как внутренних (каботажных), так и внешнеторговых грузов; 3) вывоз сырья из прибрежных районов и низовий отдельных рек и обслуживание процесса освоения углеводородов и других видов природных ресурсов.

1. Снабжение предприятий и населения арктических территорий остается важной и неизменной функцией СМП. Однако, если в западном секторе Арктики, особенно в направлениях на Дудинку (с конца 1970-х гг.), Сабетту (с 2013 г.) и Новый Порт (с 2015 г.), морской транспорт работает практически круглогодично, то в восточном секторе - только сезонно. Роль СМП в транспортном обеспечении значима для полуострова Ямал и Обской губы в Тюменской Арктике, для Норильска, Енисейского и Хатангского заливов, низовьев Енисея (до Дудинки) и Хатанги с ее притоками в Красноярской Арктике. При этом исключительно через СМП идет сезонный завоз грузов в бассейн Хатанги, тогда как для Туруханского района роль СМП сошла на нет, поскольку морской порт Игарка почти не работает, а грузы в район поступают по Енисею из Красноярска и Лесосибирска.

Вместе с тем возможности широкого участия СМП в транспортном обеспечении Арктической зоны ограничиваются природными и организационно-техническими причинами. В арктических морях, включая Карское и Лаптевых, серьезным барьером для развития эффективного судоходства являются сравнительно небольшие глубины, что существенно лимитирует грузоподъемность судов. На морских судоходных трассах глубины колеблются в пределах 20-50 м, в прибрежной полосе и на барах рек (например, на баровом участке Хатанги) могут доходить до 4 м [Проблемы..., 2006].

Если в советский период эта проблема преодолевалась использованием малотоннажных морских судов с грузоподъемностью 
5-7 тыс. т и осадкой не более 10-12 м, то к настоящему времени такие суда уже вышли из строя [Кугаевский, 2015]. Рейдовая перегрузка с современных морских судов на речные чрезвычайно усложняет и удорожает задачу доставки грузов до берега. Отсутствует также специальный мелкосидящий ледокольный флот, способный работать в прибрежной зоне и устьях сибирских рек. В Сибирской Арктике благоприятны лишь возможности перевозки грузов в направлении на Дудинку, Сабетту и Новый Порт, тогда как перспективы эффективного использования СМП для завоза грузов на других направлениях оцениваются как менее определенные.

2. Динамика транзитных перевозок по СМП крайне неустойчива: наметившийся в 2010-2013 гг. рост уже с 2014 г. сменился сокращением количества транзитных рейсов и тоннажа почти на порядок ${ }^{12}$ [Рукша и др., 2015; Поворот..., 2016]. В общем объеме перевозок по СМП в 2017 г. доля транзита не достигала и $2 \%$. Открытым остается вопрос о развитии международного транзита, его направлений и масштабов - следует учитывать, что на пути организации международных перевозок существует множество препятствий. Кроме того, стоимость арктического транзита чрезвычайно высока, и вовсе не случайно в качестве доказательства его преимуществ обычно используются показатели времени доставки, а не стоимости перевозки с учетом страховки грузов, ледокольного сопровождения и прочих расходов [Россия..., 2015].

Особо следует сказать о проблеме правового положения СМП, обострившейся в связи с отходом России от секторального принципа делимитации Северного Ледовитого океана [Проблемы..., 2006; Безруков, 2015; Россия..., 2015]. Согласно российскому законодательству, Севморпуть является исторически сложившейся национальной единой коммуникацией в Арктике, где проход иностранных судов должен осуществляться только под российским управлением и с обеспечением проводки судов российскими ледоколами. Однако, ратифицировав Конвенцию ООН по морскому праву 1982 г., Россия резко ограничила собственные возможности контроля над судоходством в своем секторе. Исходя

${ }^{12}$ Северный морской путь - только для России [Эл. ресурс]. URL: https://topwar. ru/136687-severnyy-morskoy-put-tolko-dlya-rossii.html (дата обрашения: 14.03.2018). из принятых международных норм, СМП проходит в морских акваториях с различным режимом плавания: во внутренних водах действует разрешительный порядок, в территориальных - право мирного прохода, в исключительной экономической зоне и за ее пределами - свобода судоходства.

Проблема контроля над СМП осложняется для России в связи с действием тенденции глобального потепления, в результате чего центральная часть Северного Ледовитого океана в летний период все больше освобождается ото льда. Возникает возможность приступить к освоению новых высокоширотных и приполюсных маршрутов, пролегающих вне внутренних и территориальных вод России. Преимущества этих маршрутов очевидны: во-первых, они короче традиционных прибрежных (протяженность прибрежных трасс от Мурманска до Берингова пролива составляет 3,5 тыс. миль, высокоширотных - 2,9-3,3 тыс. миль, приполюсных - 2,7 тыс. миль); во-вторых, высокоширотные и приполюсные трассы не имеют ограничений по глубинам, что дает возможность применять экономичные суда большой грузоподъемности [Актуальные, 2007]. В случае окончательной отмены принципа полярных секторов и уменьшения площади ледового покрова Россия может полностью утратить контроль над транзитным судоходством на высокоширотных и приполюсных маршрутах в Северном Ледовитом океане.

В обозримом будущем СМП не сможет составить значимой конкуренции традиционным путям морского транзита: в 2014 г. объем грузооборота через Суэцкий канал в 580 раз превышал объем международного транзита по СМП [Рукша и др., 2015], а открытие в 2015 г. второй очереди «Суэца» резко увеличило его пропускную способность. Следует согласиться с мнением экспертов в том, что наша национальная коммуникация необходима России не для обслуживания транзита китайских товаров, а для обеспечения собственных потребностей [Россия..., 2015].

3. Более прогнозируем стремительный рост значимости СМП в вывозе сырья и транспортно-логистическом обслуживании освоения прибрежных территорий. Ожидаемое «взрывное» увеличение грузопотока по СМП связано исключительно с реализацией крупных ресурсных арктических проектов. Уже в 2016 г. объем перевозок по СМП - 7,5 млн т - впервые превысил максимальный показатель советского периода (6,6 млн т 
в 1987 г.), а в 2017 г. он достиг 10,7 млн т ${ }^{13}$. Значительную часть этого объема составили экспортные поставки нефти из Нового Порта и СПГ из Сабетты, а также норильские медно-никелевые руды, вывозимые из Дудинки в Мурманск и на экспорт.

Согласно имеющимся прогнозам ${ }^{14}$, объем грузопотока по СМП к 2020 г. может достигнуть 40 млн т, к 2030 г. - 72 млн т. Основную роль в формировании этого объема к 2020 г. будут играть поставки СПГ из Сабетты («НоваТЭК»), нефти из Нового Порта (ОАО «Газпром»), угля из порта «Чайка» вблизи Диксона (УК «ВостокУголь»), медно-никелевых руд из Дудинки (ГМК «Норильский никель»). К 2030 г. к ним добавятся поставки СПГ по проекту «Арктик СПГ» («НоваТЭК»), реализуемом на Гыданском п/о-ве.

Кроме того, в перспективе возможно укрепление транспортнологистического обеспечения реализации крупных нефтегазовых проектов Красноярской Арктики: в первую очередь на базе Ванкорского кластера, во вторую - на базе месторождений Восточного Таймыра в бассейне Хатанги. Для этого требуется укрепление инфраструктуры СМП, включая модернизацию морского порта в Дудинке, создание нефтеналивных терминалов в портах Диксон и Хатанга для последующего экспорта нефти морским путем. Следует учитывать, что освоение нефтегазовых месторождений Восточного Таймыра в бассейне Хатанги серьезно затруднено сезонностью работы СМП в восточном секторе Арктики и отсутствием как круглогодичных наземных путей, так и связанных с железной дорогой судоходных речных артерий.

Особую проблему представляет разработка углеводородов на континентальном шельфе арктических замерзающих морей, где экстремальные природно-климатические условия, требующие применения новых технологий, и отсутствие транспортной инфраструктуры многократно повышают капиталоемкость подготовки

${ }^{13}$ В 2017 г. объем перевозок по Северному морскому пути вырос почти на 43\%. И это только начало [Эл. ресурc]. URL: https://neftegaz.ru/news/view/168362-V-2017-g-obemperevozok-po-Severnomu-morskomu-puti-vyros-pochti-na-43. I-eto-tolko-nachalo (дат обращения: 14.03.2018)

${ }^{14}$ Текущий (на 1.09.2017 года) прогноз Минприроды России объемов транспортировки добываемого в Арктической зоне России минерального сырья в акватории Северного морского пути на период до 2030 года [Эл. ресурс]. URL: http://docplayer.ru/70139943Tekushchiy-na-goda-prognoz-minprirody-rossii-obemov-transportirovki-dobyvaemogo-varkticheskoy-zone-rossii-mineralnogo-syrya-v-akvatorii.html (дата обращения: 14.03.2018) и освоения запасов. По мнению экспертов Института национальной стратегии [Россия..., 2015], освоение арктического шельфа страны при нынешнем уровне цен на нефть и газ экономически неэффективно. Сибирские моря Карское и Лаптевых доступны для добычи углеводородов лишь условно, так как необходимые технологии находятся еще в стадии разработки [Назаров, Калист, 2008]. Целесообразно только точечное освоение отдельных месторождений шельфа с доказанной рентабельностью, причем приоритет должен отдаваться разработке с суши и мелководным участкам вблизи берега.

Таким образом, если возможности эффективного использования СМП для традиционного завоза грузов в арктические районы ограничены (кроме нескольких направлений), а надежды на экономическое оживление под воздействием международного транзита недостаточно обоснованны, то главную роль в увеличении грузопотока по СМП и развитии Арктической зоны Сибири будет играть транспортно-логистическое обслуживание освоения прибрежных территорий, связанное с реализацией крупных ресурсных проектов. Рост перевозок морским транспортом требует коренной реконструкции всей его инфраструктуры (арктических портов, ледокольного флота, систем навигационно-гидрографического и гидрометеорологического обеспечения, авиационных и космических средств мониторинга ледовой обстановки, систем связи и управления судоходством), совершенствования тарифной политики, закрепления полного суверенитета России над СМП с использованием его для международного судоходства в рамках своей юрисдикции, прокладки новых высокоширотных глубоководных маршрутов и, соответственно, применения более мощных ледоколов и судов повышенной ледопроходимости.

\section{Литература}

Аганбегян А.Г., Ибрагимова 3. М. Сибирь на рубеже веков. М.: Советская Россия, 1984. 272 с

Актуальные проблемы Севера России: анализ и рекомендации (научноаналитический доклад). Апатиты: Изд-во Кольск. НЦ РАН, 2007. 150 с.

Бандман М.К. Енисей в системе Северного морского пути // Регион: экономика и социология. 1999. № 1. С. 98-118.

Безруков Л. А. Внутренние водные пути как фактор транспортно-экономического влияния океана // Фундаментальные проблемы изучения и использования воды и водных ресурсов. Иркутск: Изд-во ИГ СО РАН, 2005. С. 166-169. 
Безруков Л.А. Политико-географические проблемы делимитации Севера и Арктики России // География и природные ресурсы. 2015. № 4. С. 68-80.

Бондаренко Л.А., Ионова В.Д., Малов В. Ю., Тарасова О.В. Возможности формирования акватерриториально-производственных комплексов (АТПК) в зоне влияния Северного морского пути // Азиатская часть России: моделирование экономического развития в контексте опыта истории / Отв. ред. В.А. Ламин, В.Ю. Малов. Новосибирск: Изд-во СО РАН, 2012. С. 219-242. (Интеграционные проекты СО РАН; Вып. 34).

Кугаевский А. А. Транспорт восточного сектора Арктики: состояние и перспективы развития // Экономика востока России. 2015. № 1. С. 51-57.

Назаров В.И., Калист Л. В. Геолого-экономическая оценка ресурсов нефти и газа акваторий морей России // Минеральные ресурсы России. Экономика и управление. 2008. № 3. С. 26-31.

Поворот на Восток: Развитие Сибири и Дальнего Востока в условиях усиления азиатского вектора внешней политики России /Отв. ред. И.А. Макаров. М.: Международные отношения, 2016. 448 с.

Пономарев В. Третий заход // Эксперт. 2017. № 13. С. 46-49. (Спец. обозрение «Освоение Арктики»).

Проблемы Северного морского пути /Отв. ред. ак. А. Г. Гранберг, В. И. Пересыпкин. М.: Наука, 2006. 581 с.

Россия в Арктике. Вызовы и перспективы освоения /Под ред. М. В. Ремизова. М.: Ин-т национ. стратегии, Книжный мир, 2015. 384 с.

Рукша В.В., Белкин М.С., Смирнов А.А., Арутюнян В.Г. Структура и динамика грузоперевозок по Северному морскому пути: история, настоящее и перспективы // Арктика: экология и экономика. 2015. № 4. С. 104-110.

Статья поступила 19.03.2018

\section{Summary}

Bezrukov L.A., V.B. Sochava Institute of Geography SB RAS, Irkutsk

Problems of formation of the transport system of Siberian Arctic

Topical issues of transport development of the Arctic territories of Siberia Tyumen and Krasnoyarsk regions are considered. The main achievements in the development of transport of the Tyumen Arctic, consisting in the acquisition of new important functions for the transportation of oil and liquefied natural gas with the Northeast Passage (NEP), progressive construction of the ground communication infrastructure - railways and year-round motorways, are disclosed. Shortcomings in the development of the transport system of the Krasnoyarsk Arctic are noted, they are expressed in the presence of almost exclusively seasonal routes with the dominance of river and sea transport, absence of alternative transport schemes and the extremely high level of transportation costs. An analysis of the priorities and functions of the NEP has been made, its growing importance has been confirmed mainly in transport and logistics services for large oil and gas and other resource projects and export of raw materials from the coastal areas to the external and internal markets.

Tyumen and Krasnoyarsk Arctic; Northeast Passage (NEP); transport development and maintenance; year-round land routes; season routes; cargo delivery, freight traffic; transit transport

\section{References}

Aganbegjan A. G., Ibragimova Z.M. (1984) Sibir' na rubezhe vekov. Moscow. Sov. Rossija. Rubl. 272 p. (In Russ.)

Aktual'nye problemy Severa Rossii: analiz i rekomendacii (nauchnoanaliticheskij doklad). (1999) Apatity. Izd-vo Kol'sk. NC RAN Rubl., 2007. 150 p (In Russ.)

Bandman M.K. (1999) Enisej v sisteme Severnogo morskogo puti. Region: jekonomika i sociologija [Region: Economics and Sociology]. No. 1. Pp. 98-118 (In Russ.)

Bezrukov L.A.(2005). Vnutrennie vodnye puti kak faktor transportnojekonomicheskogo vlijanija okeana. Fundamental'nye problemy izuchenija i ispol'zovanija vody i vodnye resursov. Irkutsk. Izd-vo IG SO RAN Rubl. Pp. 166-169. (In Russ.)

Bezrukov L.A. (2015) Politiko-geograficheskie problemy delimitacii Severa i Arktiki Rossii. Geografija i prirod. resursy [Geography and natural resources]. No. 4. Pp. 68-80. (In Russ.)

Bondarenko L.A., Ionova V. D., Malov V. Ju., Tarasova O. V.(2012). Vozmozhnosti formirovanija akvaterritorial'no-proizvodstvennyh kompleksov (ATPK) v zone vlijanija Severnogo morskogo puti. Aziatskaja chast' Rossii: modelirovanie jekonomicheskogo razvitija $\mathrm{v}$ kontekste opyta istorii. Otv. red. V.A. Lamin, V. Ju. Malov. Novosibirsk: SO RAN Rubl. Pp. 219-242. (Integracionnye proekty SO RAN; Vyp. 34). (In Russ.)

Kugaevskij A.A. (2015) Transport vostochnogo sektora Arktiki: sostojanie i perspektivy razvitija. Jekonomika vostoka Rossii [Economy of the East of Russia] No. 1. Pp. 51-57. (In Russ.)

Nazarov V.I., Kalist L.V. (2008) Geologo-jekonomicheskaja ocenka resursov nefti i gaza akvatorij morej Rossii. Mineral'nye resursy Rossii. Jekonomika i upravlenie [Mineral resources of Russia. Economics and Management]. No. 3. Pp. 26-31. (In Russ.)

Povorot na Vostok: Razvitie Sibiri i Dal'nego Vostoka v uslovijah usilenija aziatskogo vektora vneshnej politiki Rossii (2016). Otv. red. I. A. Makarov. Moscow. Mezhdunarodnye otnoshenija,. 448 p. (In Russ.)

Ponomarev V. (2017) Tretij zahod. Jekspert [Expert]. No. 13. Pp. 46-49. (Spec. obozrenie «Osvoenie Arktiki»). (In Russ.)

Problemy Severnogo morskogo puti (2006). Otv. red. ak. A.G. Granberg, V.I. Peresypkin. Moscow. Nauka Rubl. 581 p. (In Russ.)

Rossija v Arktike. Vyzovy i perspektivy osvoenija (2015) Pod red M. V. Remizova. Moscow In-t nacional. strategii, Knizhnyj mir Rubl. 384 p. (In Russ.)

Ruksha V.V., Belkin M. S., Smirnov A.A., Arutjunjan V.G. (2015) Struktura i dinamika gruzoperevozok po Severnomu morskomu puti: istorija, nastojashhee i perspektivy. Arktika: jekologija i jekonomika [Arctic: Ecology and Economy] No. 4. Pp. 104-110 